BACTERIOLOGY/RICE STRAW

J. Natn. Sci. Coun. Sri Lanka 1995 23(1): 25-30

\title{
ISOLATION AND CHARACTERIZATION OF CELLULOLYTIC BACTERIA FROM DECOMPOSING RICE STRAW
}

\author{
D.M. SIRISENA* and T.P. MANAMENDRA \\ Department of Botany, University of Kelaniya, Kelaniya.
}

(Received : 25 August 1994; accepted : 29 January 1995)

\begin{abstract}
Three cellulolytic bacterial strains were isolated from decomposing rice straw. They were able to utilize cellulose, rice straw powder and carboxymethylcellulose as substrates. Two of these strains, Listeria sp. and Enterobacter sp., were abundant during initial stages of decomposition whereas the other strain, Pseudomonas sp., became dominant towards the late stages of the process: Comparison of their endo-1, 4- $\beta$-glucanase (carboxymethylcellulase) activity by indirect methods indicated a higher level of enzymatic activity in the Pseudomonas sp. than in the other two strains. Release of glucose by saccharification of cellulose and carboxymethylcellulose was also higher with Pseudomonas sp. compared with Listeria sp.
\end{abstract}

Key words: Cellulase, cellulolytic bacteria, lignocellulose, rice straw.

\section{INTRODUCTION}

Most agricultural residues of crop plants, particularly cereals, are rich in lignocellulosic materials. ${ }^{1,2}$ Cellulose, a long-chain polysaccharide made of $\beta(1,4)$-linked glucose units, is the principal constituent of lignocelluloses. Association of cellulose with lignin, another complex polymeric molecule composed of phenylpropanoid units, forms the lignocelluloses. Hemicellulose is the other major component of lignocelluloses. It is a heterogeneous group of long-chain polysaccharides of which basic units are arabinose, xylose, mannose or galactose. Degradation of lignocellulosic material is a slow process and only a relatively narrow taxonomic range of bacteria and fungi are able to degrade such material. The ability of microorganisms to degrade cellulosic material is of considerable interest both in terms of microbial ecology and biotechnology.

Degradation of cellulosic material requires the cooperative action of a family of cellulolytic enzymes that have been classified into three major groups: endoglucanases (EC3.2.1.4), exoglucanases (EC 3.2.1.91) and $\beta$-glucosidases (EC 3.2.1.21). ${ }^{3}$ Cellulolytic properties of these enzymes have been studied mostly in fungi. ${ }^{4}$ The bacterial cellulase system has only recently become a focus of investigation. Due to high cellulolytic activity of some bacteria and their short generation time they are a more promising group of organisms in degrading lignocellulosic wastes. ${ }^{5}$ In this paper we report isolation and characterization of three cellulolytic bacterial strains involved in the degradation of rice straw, a widely available agricultural residue in Sri Lanka.

- Corresponding author. 


\section{METHODS AND MATERIALS}

\section{Isolation of bacteria from rice straw}

Rice straw samples representing different stages of the process of decomposition, starting from one week after harvesting, were used for this study. Each sample $(5 \mathrm{~g})$ was washed with $15 \mathrm{ml}$ of sterile $0.07 \mathrm{M}$ potassium phosphate buffer, $\mathrm{pH} 7.2$, with vigorous shaking and the washing was filtered through two Whatman $3 \mathrm{MM}$ filter papers. From each filtrate a dilution series $\left(10^{-1}-10^{-4}\right)$ was prepared using sterile potassium phosphate buffer, $\mathrm{pH} 7.2$, and $0.1 \mathrm{ml}$ samples were spread on L- agar (10g tryptone, $5 \mathrm{~g}$ yeast extract, $10 \mathrm{~g} \mathrm{NaCl}, 1 \mathrm{~g}$ glucose and $15 \mathrm{~g}$ agar per liter $)^{6}$ plates and incubated at $37^{\circ} \mathrm{C}$.

\section{Identification of cellulolytic bacteria}

Different types of bacteria from L-agar plates were inoculated onto the cellulose agar (2.5 g of precipitated cellulose, $0.5 \mathrm{~g}$ peptone, $0.2 \mathrm{~g}$ dipotassium-hydrogen phosphate, $0.2 \mathrm{~g}$ magnesium sulphate, $0.4 \mathrm{~g}$ potassium carbonate, $0.02 \mathrm{~g}$ calcium chloride, ferrous sulphate and sodium chloride, and $15 \mathrm{~g}$. Oxoid ion agar per liter) and incubated at $37^{\circ} \mathrm{C}$. Only the bacterial strains capable of degrading cellulose grow well on this medium. None of these strains grew on the agar medium without cellulose. Thus, several cellulolytic bacterial strains were isolated and on the basis of morphological and biochemical characteristics they were identified to the genus level.

\section{Confirmation of cellulolytic activity}

Bacterial strains identified as cellulase positive were further tested for their cellulolytic activity by growing in media containing rice straw powder or carboxymethylcellulose (CMC) ( $\mathrm{BDH}$, high viscosity), a semisynthetic cellulosic substrate.

\section{Visualization of CMC ( $\beta$-D-Glucan) hydrolysis}

One of the enzymes required to convert cellulose to glucose is endo- $1,4-\beta$ glucanase, ${ }^{7}$ which can be detected by the hydrolysis of CMC. Enzymic activity of the isolated bacterial strains was visualized as described ${ }^{8}$ with a slight modification. Inoculum from each fresh bacterial culture was patched on CMC agar which contained CMC (1 mg/ml) instead of cellulose in the cellulose agar medium, and incubated at $37^{\circ} \mathrm{C}$ for $8 \mathrm{~h}$. Plates were then flooded with an aqueous solution of congo red for $15 \mathrm{~min}$. After pouring off the congo red solution, plates were flooded with $1 \mathrm{M} \mathrm{NaCl}$ for $15 \mathrm{~min}$. After that zones of hydrolysis could be seen as clear areas.

\section{Release of glucose by saccharification of cellulose and CMC}

Cellulose broth containing $0.5 \%$ cellulose $(\mathrm{w} / \mathrm{v})$ and all the other ingredients except agar found in the cellulose agar medium was used to determine the 
saccharification of cellulose. CMC broth was prepared using $0.5 \% \mathrm{CMC}(\mathrm{w} / \mathrm{v})$ instead of cellulose. Samples of bacterial cultures $(0.5 \mathrm{ml}) \mathrm{grown}$ in these broths to a same cell density were used to inoculate $50 \mathrm{ml}$ of fresh broth in $250 \mathrm{ml}$ flasks. These cultures were incubated at $37^{\circ} \mathrm{C}$ with continuous shaking, for $.24 \mathrm{~h}$, and then centrifuged at $5000 \mathrm{~g}$ for $10 \mathrm{~min}$. Glucose concentration of the supernatants were determined as described.9 A $0.1 \mathrm{ml}$ sample of the supernatant was boiled with $5 \mathrm{ml} o$-toluidine for $10 \mathrm{~min}$, and $\mathrm{OD}_{635}$ was determined. Corresponding glucose concentration was read from a standard calibration curve of glucose concentration $(\mathrm{O}-15 \mathrm{mmol} / \mathrm{h})$.

\section{RESULTS}

L-agar plates prepared with diluted straw-washings were used initially to determine different types of bacteria present at various stages of decomposition (sampling period was from one week after harvesting to three months). In all samples there were three prominent types of bacteria that could be distinguished by their colony characteristics. Only these strains grew on cellulose agar demonstrating their cellulolytic activity. Morphological and biochemical characterisitics showed that these strains belong to the genera Pseudomonas, Listeria and Enterobacter (Table 1).

Table 1: Characteristics used to identify the bacterial strains

\begin{tabular}{|c|c|c|c|c|}
\hline \multicolumn{2}{|l|}{ Characteristics } & Listeria sp. & Enterobacter sp. & Pseudomonas sp. \\
\hline Gram's reaction & & $\mathbf{G}^{+}$ & $G^{-}$ & G- \\
\hline Cell shape & & Irregular rods & Rods & Rods \\
\hline Motility & & $t^{a}$ & + & + \\
\hline Oxidase & & $-b$ & - & + \\
\hline Acid production from & sucrose & + & + & + \\
\hline & lactose & + & + & + \\
\hline & galactose & + & + & $N^{c}$ \\
\hline . & arabinose & + & NT & NT. \\
\hline & maltose & NT & + & NT \\
\hline & mannitol & NT & + & NT \\
\hline Methyl Red test & & + & + & + \\
\hline Urease & & - & - & - \\
\hline Voges-Proskauer test & & - & - & \\
\hline Indole test & & + & + & + \\
\hline Nitrate reduction & & + & + & + \\
\hline Starch hydrolysis & & + & NT & - \\
\hline Utilization of citrate & & NT & + & NT \\
\hline Growth in $\mathrm{KCN}$. & & NT & + & NT \\
\hline Cellulose hydrolysis & & + & NT & NT \\
\hline
\end{tabular}

a - Positive result or growth, b - Negative result or no growth, $c$ - Not tested.

These three strains were present in similar numbers in the straw samples which were less than one month old. However, in the samples taken from straw 
older than one month, Pseudomonas sp. was abundant while the numbers of the other two strains gradually decreased (Table 2).

Table 2: Bacterial counts in straw-washings prepared from straw in different stages of decomposition.

\begin{tabular}{lccc}
\hline $\begin{array}{c}\text { Age of the straw } \\
\text { sample }\end{array}$ & Pseudomonas sp. & $\begin{array}{c}\text { No. of cells } / \mathrm{ml}^{\mathrm{a}} \\
\text { Listeria } \mathrm{sp} .\end{array}$ & Enterobacter sp. \\
\hline 1 week & $4.5 \times 10^{4}$ & $4.8 \times 10^{4}$ & $5.0 \times 10^{4}$ \\
1 month & $4.7 \times 10^{4}$ & $4.5 \times 10^{4}$ & $3.8 \times 10^{4}$ \\
2 months & $2.5 \times 10^{4}$ & $2.2 \times 10^{4}$ & $2.0 \times 10^{4}$ \\
3 months & $6.0 \times 10^{5}$ & $1.8 \times 10^{3}$ & $1.0 \times 10^{3}$ \\
\hline
\end{tabular}

a - Average of the number of colonies in plates inoculated with samples from a serial dilution $\left(10^{-1}-10^{-4}\right)$ of straw washings.

All three strains grew well in the media containing CMC, and rice straw powder, confirming their ability to utilize these cellulosic substrates. The Congo red method used to visualize the hydrolysis of CMC enabled comparison of the endo- $\beta$-1,4-glucanase activity of the three strains. Pseudomonas sp. produced the largest zone of hydrolysis (Fig. 1A) (clear zone) indicating a high level of enzymatic activity. Zones of hydrolysis produced by Listeria sp. (Fig. 1B.1) and the Enterobacter sp. (Fig. 1B.2) were similar in size, but they were smaller than the zones produced by the Pseudomonas sp. This suggests that the level of their enzymatic activity is similar to but less than that of Pseudomonas.

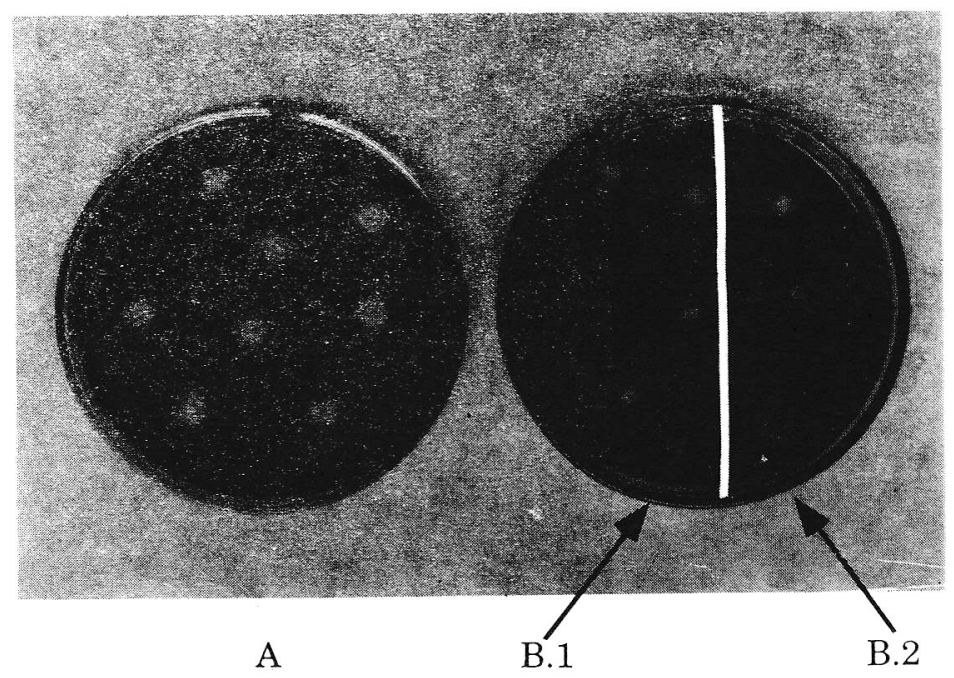

Figure 1: Endo-1,4-• $\beta$-glucanase activity of the isolated bacterial strains visualized as clear zones of hydrolysis. Bacterial colonies were grown on CMC agar and then plates were stained with Congo red to visualize the clear zone. (A) Pseudomonas sp, (B.1) Listeria sp, (B.2) Enterobacter sp. 
Release of glucose by the saccharification of cellulose and CMC was examined only with the Pseudomonas sp. and Listeria sp. Pseudomonas sp. released 2.0 and $1.8 \mathrm{mmol} / /$ glucose when cellulose and CMC were used respectively. Concentrations of glucose produced by Listeria $\mathrm{sp}$. were $1.8 \mathrm{mmol} / \mathrm{w}$ with cellulose and $1.5 \mathrm{mmol} / 1$ with CMC.

\section{DISCUSSION}

Cellulolytic bacterial strains isolated from decomposing rice straw were able to utilize both natural and semi-synthetic cellulosic substrates. Variation of the frequency of occurrence of these three genera with time is evidence of existence of a cellulolytic bacterial succession on this substrate. The role of Listeria sp. and Enterobacter sp. seems to be more important during the early stages of decomposition. Increasing frequency of the Pseudomonas sp. after about one month suggests that the action of the enzymes produced by this strain is required during the later stages. As detected from the congo red method, this Pseudomonas sp. has a high level of endo-1,4- $\beta$-glucanase activity. This is one of the enzymes required for the conversion of cellulose to glucose. Saccharification of wheat straw yields a number of products including reducing sugars xylose and glucose. ${ }^{10}$ Since glucose or its oligomers have not been found in cereal straw hemicellulose fractions, ${ }^{11}$ the production of glucose confirms hydrolysis of the cellulose component of straw. Release of high amounts of glucose from both cellulose and CMC by Pseudomonas sp. compared to the amounts of released glucose with Listeria sp. confirms its high level of production of extracellular cellulases. Pseudomonas sp. with cellulase activity has been isolated previously. ${ }^{12}$ Pseudomonas sp. isolated in the present study appears to have high cellulase activity in com parison with the bacteria isolated earlier ${ }^{12}$ and may be suitable for genetic manipulation to achieve a higher efficiency of degradation of rice straw.

\section{References}

1. Lynch J.M. (1987). Utilization of lignocellulosic waste. Journal of Applied Bacteriology (Symposium supplement). 71s - 73s.

2. Milstein O., Bechar A., Shragina L. \& Gressel A. (1987). Solar pasteurization of straw for nutritional upgrading and as substrate for lignolytic organisms. Biotechnology Letters 9: 269-274.

3. Knowles J., Lehtovaara P. \& Teeri T. (1987). Cellulase genes and their families. Trends in Biotechnology 5: 255-261.

4. Okeke B.C. \& Obi S.K.C. (1993). Production of cellulolytic and xylanolytic enzymes by an Arthrographis species. World Journal of Microbiology and Biotechnology 6 : 345-349.

5. Gijzen H.J., Lubberding H.J., Verhagen F.J., Zwart K.B. \& Vogelș G.D. (1987). Application of rumen microorganisms for enhanced anaerobic degradation of solid organic waste materials. Biological Wastes 22: 81-95. 
6. Lennox E.S. (1955). Transduction of linked genetic characters of the host by bacteriophage PL. Virology 1: 109-206.

7. Silva J., Saloheimo M., Montanez C., Knowels J.K.C. \& Teeri T.T. (1988). Molecular cloning of cellulolytic enzyme genes from Cellulomonas flavigena in $E$. coli. Journal of Biotechnology $8 ; 249-256$.

8. Teather R.M. \& Wood P.J. (1982). Use of congo red-polysaccharide interactions in enumeration and characterization of cellulolytic bacteria from the bovine rumen. Applied and Environmental Microbiology 43: 777-780.

9. Ball A.S., Brabban A. \& McCarthy A.J. (1992). Studies on the extracellular p-nitrophenyl $\beta$-D-cellobiosidase activity of a thermophilic streptomycete. Applied Microbiology \& Biotechnology 36 : 473-477.

10. Ball A.S. \& McCarthy A.J. (1988). Saccharification of straw by actinomycete enzymes. Journal of General Microbiology 134 : 2139-2147.

11. Whistler R.L.A. \& Richards E.L. (1970). Hemicellulose. In The Carbohydrates, (Ed. W Pigman \& D Horton), pp. 447-469. Academic Press, London.

12. Malek M.A., Chowdhury N.A., Youssouf Q.M. \& Chowdhury N. (1988). Bacterial cellulases and saccharification of lignocellulosic materials. Enzyme and Microbial Technology 10 : 750-753. 